\title{
Tropospheric aerosol as a reactive intermediate $\dagger$
}

\author{
Agustín J. Colussi, ${ }^{* a}$ Shinichi Enami, ${ }^{\text {bocd }}$ Akihiro Yabushita, ${ }^{\text {e }}$ \\ Michael R. Hoffmann, ${ }^{a}$ Wei-Guang Liu, ${ }^{f}$ Himanshu Mishra ${ }^{a}$ \\ and William A. Goddard, III $^{\mathrm{f}}$
}

Received 14th March 2013, Accepted 3rd April 2013

DOI: $10.1039 / \mathrm{c} 3 \mathrm{fd} 00040 \mathrm{k}$

In tropospheric chemistry, secondary organic aerosol (SOA) is deemed an end product. Here, on the basis of new evidence, we make the case that SOA is a key reactive intermediate. We present laboratory results on the catalysis by carboxylate anions of the disproportionation of $\mathrm{NO}_{2}$ 'on water': $2 \mathrm{NO}_{2}+\mathrm{H}_{2} \mathrm{O}=\mathrm{HONO}+\mathrm{NO}_{3}{ }^{-}+\mathrm{H}^{+}(\mathrm{R} 1)$, and supporting quantum chemical calculations, which we apply to reinterpret recent reports on (i) HONO daytime source strengths vis-à-vis SOA anion loadings and (ii) the weak seasonal and latitudinal dependences of $\mathrm{NO}_{x}$ decay kinetics over several megacities. HONO daytime generation via R1 should track sunlight because it is generally catalyzed by the anions produced during the photochemical oxidation of pervasive gaseous pollutants. Furthermore, by proceeding on the everpresent substrate of aquated airborne particulates, R1 can eventually overtake the photolysis of $\mathrm{NO}_{2}: \mathrm{NO}_{2}+\mathrm{h} v=\mathrm{NO}+\mathrm{O}\left({ }^{3} \mathrm{P}\right)(\mathrm{R} 2)$, at large zenith angles. Thus, since R1 leads directly to $\mathrm{OH}$-radical generation via HONO photolysis: $\mathrm{HONO}+h v=\mathrm{NO}+\mathrm{OH}$, whereas the path initiated by $\mathrm{R} 2$ is more circuitous and actually controlled by the slower photolysis of $\mathrm{O}_{3}: \mathrm{O}_{3}+h v\left(+\mathrm{H}_{2} \mathrm{O}\right)=\mathrm{O}_{2}+2 \mathrm{OH}$, the competition between R1 and R2 provides a mechanistic switch that buffers $\mathrm{OH}$ concentrations and $\mathrm{NO}_{2}$ decay (via $\mathrm{R} 1$ and/or $\mathrm{NO}_{2}+\mathrm{OH}=\mathrm{HNO}_{3}$ ) from actinic flux variations.

\footnotetext{
${ }^{a}$ Ronald and Maxine Linde Center for Global Environmental Science, California Institute of Technology, Pasadena, California 91125, USA. E-mail: ajcoluss@caltech.edu

${ }^{b}$ The Hakubi Center for Advanced Research, Kyoto University, Kyoto 606-8302, Japan. E-mail: enami.shinichi. 3r@kyoto-u.ac.jp

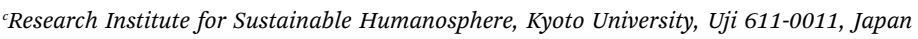

${ }^{d}$ PRESTO, Japan Science and Technology Agency, Kawaguchi 332-0012, Japan

${ }^{e}$ Department of Molecular Engineering, Kyoto University, Kyoto 615-8510, Japan

${ }^{f}$ Materials and Process Simulation Center, California Institute of Technology, Pasadena, California 91125, USA

$\dagger$ Electronic supplementary information (ESI) available: Further experimental details, additional data and information. See DOI: 10.1039/c3fd00040k
} 


\section{Introduction}

More than half of the world population inhabits rapidly expanding conurbations with increasing per capita energy needs. ${ }^{1}$ Assessing the impact of these combined trends on air pollution, human health and quality of life in megacities is therefore a pressing issue. $^{2-4}$ This goal is being approached via three-dimensional chemical transport models that include pollutant emissions, transport, removal, gas-phase chemistry and aerosol physics..$^{5-10}$ Since 'the key to understanding tropospheric chemistry begins with the $\mathrm{OH}$ radical ${ }^{7}$ a mandatory test for any model is how well it reproduces $\mathrm{OH}$ radical concentrations under diverse conditions. ${ }^{11}$ The chemistry of nitrogen oxides $\left(\mathrm{NO}_{x}\right)$ plays an essential role in the production of $\mathrm{OH}$ radicals, which can be triggered by the photolysis of $\mathrm{NO}_{2}$, reaction $\mathrm{R} 2$, followed by reactions $\mathrm{R} 3-\mathrm{R} 5:^{7,12,13}$

$$
\begin{gathered}
\mathrm{NO}_{2}+h \nu(\lambda<422 \mathrm{~nm})=\mathrm{NO}+\mathrm{O}\left({ }^{3} \mathrm{P}\right) \\
\mathrm{O}_{2}+\mathrm{O}\left({ }^{3} \mathrm{P}\right)=\mathrm{O}_{3} \\
\mathrm{O}_{3}+h \nu(\lambda<340 \mathrm{~nm})=\mathrm{O}_{2}+\mathrm{O}\left({ }^{1} \mathrm{D}\right) \\
\mathrm{O}\left({ }^{1} \mathrm{D}\right)+\mathrm{H}_{2} \mathrm{O}=2 \mathrm{OH}
\end{gathered}
$$

The augmented strength of nitrogen oxides $\left(\mathrm{NO}_{x}\right)$ emissions in megacities (from internal combustion engines used in transportation) poses a critical test to current models. . $^{\mathbf{2 , 1 4 , 1 5}}$

Reliable air quality forecast models should have the ability to simulate the composition of the troposphere in most locations throughout the year. ${ }^{3,16}$ This is a major challenge, because some pollutants, such as particulate matter, ${ }^{17}$ are always present in significant amounts, ${ }^{18}$ whereas others, such as $\mathrm{O}_{3}$, peak in summer. Disappointingly, current models generally fare poorly in predicting how $\mathrm{OH}$ concentrations respond to actinic flux and $\mathrm{NO}_{x}$ levels, ${ }^{11}$ and systematically underpredict HONO concentrations. ${ }^{11,16,19}$ The strong direct correlation between tropospheric $\mathrm{OH}$ concentrations and solar ultraviolet radiation: $[\mathrm{OH}] \propto J\left(\mathrm{O}^{1} \mathrm{D}\right)^{\beta},{ }^{20}$ detected at a pristine site yearlong, ${ }^{21}$ and episodically at a polluted one, ${ }^{22}$ is not well reproduced by standard chemical models. ${ }^{22-24}$ Even more troubling is that, contrary to expectations, noon-time $\mathrm{OH}$ concentrations (in Birmingham) during winter were found to be only a factor of 2 smaller than in summer, despite a factor of 15 reduction in $J\left(\mathrm{O}^{1} \mathrm{D}\right)$ over the same period..$^{25}$ Given the key role of $\mathrm{OH}$, this represents a major deficiency in our understanding of tropospheric chemistry. It has been suggested that the diminished solar photolysis of $\mathrm{O}_{3}$ in winter could be supplemented by that of HONO, ${ }^{16,26-30}$ reaction R6,

$$
\mathrm{HONO}+h \nu(\lambda<396 \mathrm{~nm})=\mathrm{NO}+\mathrm{OH}
$$

which is driven at longer wavelengths than R4 and, hence, will still proceed at significant rates at low zenith angles. Since R6 is fast (HONO half-life $\sim 10 \mathrm{~min}$ ) this proposal in effect calls for an unspecified process that causes HONO daytime production to be competitive with $\mathrm{NO}_{2}$ photolysis, $\mathrm{R} 2 .{ }^{31-34}$ The missing process is likely heterogeneous, ${ }^{19,35-39}$ must obviously track sunlight and be able to reduce $\mathrm{N}(\mathrm{Iv}) \mathrm{O}_{2}$ into $\mathrm{HON}(\mathrm{III}) \mathrm{O}$ under the prevailing oxidizing conditions. ${ }^{40}$ Reaction R1:

$$
2 \mathrm{NO}_{2}+\mathrm{H}_{2} \mathrm{O}=\mathrm{HONO}+\mathrm{NO}_{3}{ }^{-}+\mathrm{H}^{+}
$$


may meet these requirements but, since it entails the concomitant termination of $\mathrm{NO}_{2}$ as $\mathrm{NO}_{3}{ }^{-}$, its likelihood rests on whether is consistent with the kinetics of $\mathrm{NO}_{2}$ decay in the field. Herein, we address this outstanding issue in tropospheric chemistry via a meta-analysis of recent field measurements on HONO daytime sources and $\mathrm{NO}_{2}$ decay in urban plumes from the perspective of our new results on the catalysis by organic anions of $\mathrm{NO}_{2}$ uptake on water.

The objective of this paper is to present an explicit chemical mechanism for R1, and show that its operation on wet SOA accounts for a suite of apparently unrelated, hitherto unexplained observations. The paper is organized as follows: we (1) report new laboratory results obtained by a novel technique developed in our laboratory ${ }^{\mathbf{4 1 4}}$ on the catalysis by dicarboxylic acid anions of the hydrolytic disproportionation of $\mathrm{NO}_{2}(\mathrm{~g})$ on aqueous surfaces (reaction R1) ${ }^{45-47}$ as well as supporting quantum mechanical calculations and (2) show that such anions are normally produced in urban SOA from the photochemical oxidation of volatile organic compounds (VOCs). ${ }^{48}$ We then review and summarize pertinent information on aerosol optical depth time series data over megacities, ${ }^{\mathbf{4 9 , 5 0}}$ and solar photolysis frequencies $J\left(\mathrm{NO}_{2}\right), J\left(\mathrm{O}^{1} \mathrm{D}\right)$ and $J(\mathrm{HONO})$ as functions of season and latitude. ${ }^{20}$ On this factual basis, we provide a novel interpretation of recently reported data on the quantification of the unknown HONO daytime source, ${ }^{26}$ and seasonally-averaged daytime $\mathrm{NO}_{2}$ decay lifetimes over several megacities. ${ }^{51}$

\section{Experimental results}

In our experiments we expose continuously flowing aqueous microjets to a steady, orthogonal stream of $\mathrm{NO}_{2}(\mathrm{~g})$ (at ppmv levels in a $\mathrm{N}_{2}$ gas carrier) for a few tens of $\mu \mathrm{s}$ under ambient ( $1 \mathrm{~atm}$ total pressure, at $293 \mathrm{~K}$ ) conditions, while detecting the $\mathrm{NO}_{3}{ }^{-}$produced in reactive gas $\mathrm{NO}_{2}(\mathrm{~g})$-liquid collisions via online electrospray ionization mass spectrometry (ESI-MS). A full description of the instrument and its operation in similar experiments can be found in previous publications from our laboratory. ${ }^{\mathbf{4 1 - 4 3 , 4 7}}$ Specific details are provided as Supplementary Information (ESI), $\dagger$ which includes a diagram of the reaction zone (Fig. S1 $\dagger$ ). The decisive advantages of online ESI-MS over other techniques are that it (i) operates in situ, i.e., avoids sample manipulation, (2) is fast: gas-liquid reaction times are a few tens of $\mu \mathrm{s},{ }^{52}$ and products are detected within $\sim 1 \mathrm{~ms}$, (3) is mass-selective, thereby providing unequivocal identification of ionic reactants and products, (4) has high sensitivity, with routine detection limits down to $0.1 \mu \mathrm{M}$, allowing experiments approach realistic conditions, (5) minimizes surface contamination, because reactive gas-liquid events take place on fast-flowing, continuously refreshed liquid microjets. We have previously demonstrated that our experiments are surface specific by showing that anion signal intensities in the mass spectra of equimolar salt solutions, rather than being identical follow a normal Hofmeister series, ${ }^{53,54}$ and detect products of gas-liquid reactions that could only be formed at the air-water interface. ${ }^{\mathbf{1 1}}$

The basic information provided by these experiments is how $m / z=62 \mathrm{NO}_{3}{ }^{-}$ signal intensities, $I_{62}$, vary as functions of the composition of the aqueous microjets and the partial pressure of $\mathrm{NO}_{2}(\mathrm{~g})$ in the impinging streams. The initial composition of the aqueous microjets ranged from deionized water to sub-mM solutions of malonic acid (MA, HOOC- $\mathrm{CH}_{2}-\mathrm{COOH}$ ), glutaric acid (GTR, HOOC$\left.\left(\mathrm{CH}_{2}\right)_{4}-\mathrm{COOH}\right)$ or glutamic acid (GTM, HOOC- $\left.\left(\mathrm{CH}_{2}\right)_{3}-\mathrm{CH}_{2}\left(\mathrm{NH}_{2}\right)-\mathrm{COOH}\right)$ as 


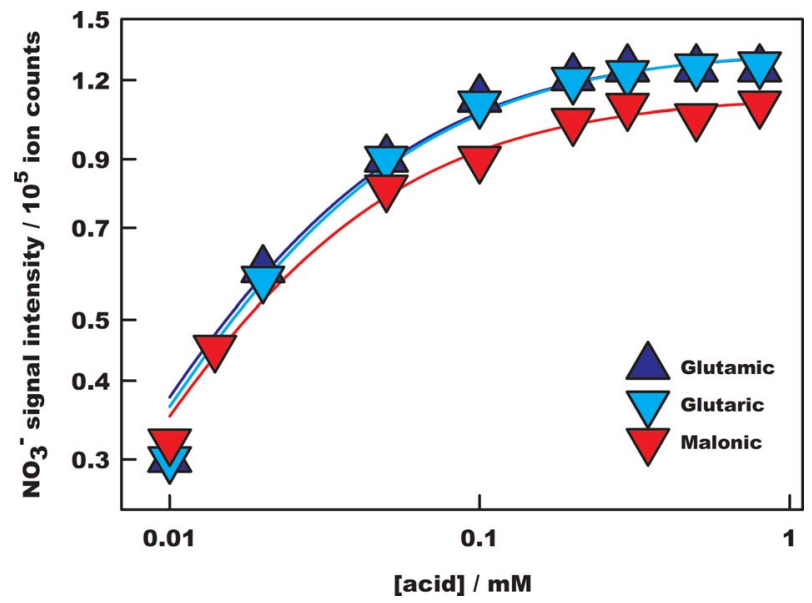

Fig. $1 \mathrm{ESI}-\mathrm{MS} \mathrm{NO}_{3}{ }^{-}(\mathrm{m} / \mathrm{z}=62)$ signal intensities from aqueous microjets containing glutamic, malonic or glutaric acids at variable concentrations, adjusted to $\mathrm{pH} 7$ and exposed to $2 \mathrm{ppmv}\left[\mathrm{NO}_{2}(\mathrm{~g})\right]$ for $\sim 10 \mu$ s. All experiments under $1 \mathrm{~atm} \mathrm{~N}_{2}(\mathrm{~g})$ at $293 \mathrm{~K}$.

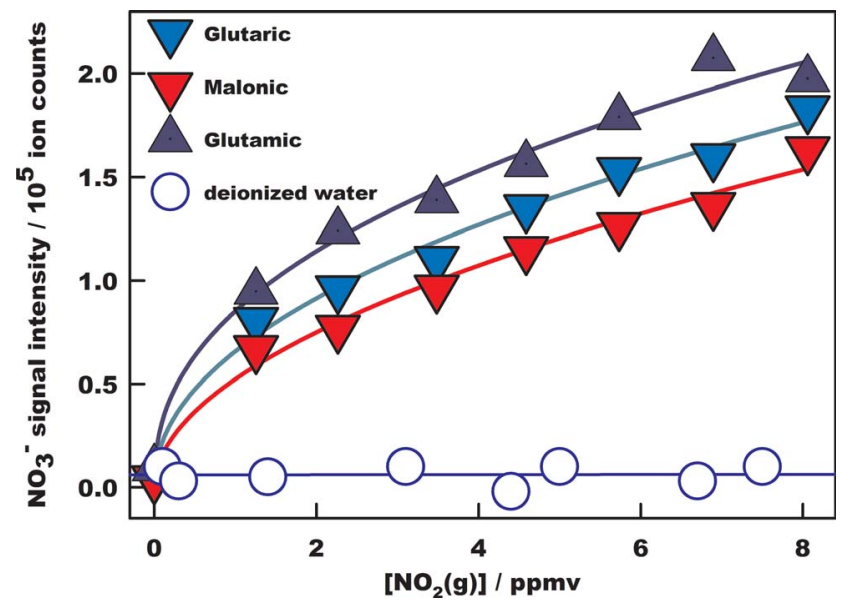

Fig. 2 ESI-MS $\mathrm{NO}_{3}{ }^{-}(\mathrm{m} / \mathrm{z}=62)$ signal intensities from aqueous microjets containing $1 \mathrm{mM}$ glutamic, malonic or glutaric acids at $\mathrm{pH} 7$ exposed to variable concentrations of $\mathrm{NO}_{2}(\mathrm{~g})$ for $\sim 10 \mu \mathrm{s}$. All experiments under $1 \mathrm{~atm} \mathrm{~N}_{2}(\mathrm{~g})$ at $293 \mathrm{~K}$.

representatives of the dicarboxylic acids found in SOA. ${ }^{48,55}$ We monitored $\mathrm{NO}_{3}{ }^{-}$ formation in experiments comprising (1) aqueous microjets of varying dicarboxylic acid concentrations under $2 \mathrm{ppmv} \mathrm{NO}_{2}$ (g) (Fig. 1) $\left(1 \mathrm{ppmv}=2.5 \times 10^{13}\right.$ molecules $\mathrm{cm}^{-3}$ at $1 \mathrm{~atm}, 293 \mathrm{~K}$. See supplementary Fig. S2 $\dagger$ ), (2) $1 \mathrm{mM}$ carboxylic acid microjets exposed to variable $\mathrm{NO}_{2}(\mathrm{~g})$ concentrations (Fig. 2).

Confirming previous experiments in our laboratory ${ }^{45-47}$ and others, ${ }^{56-58}$ we found that $\mathrm{NO}_{3}{ }^{-}$signals remained at or below noise level on deionized water microjets up to the highest $\mathrm{NO}_{2}(\mathrm{~g})$ concentrations $\left(\mathrm{NO}_{2}(\mathrm{~g})<8 \mathrm{ppmv}=2 \times 10^{14}\right.$ molecules $\mathrm{cm}^{-3}$, Fig. 2). This observation is consistent with the generations of $<0.1 \mu \mathrm{M} \mathrm{NO}_{3}^{-}\left(<6 \times 10^{13}\right.$ ions $\left.\mathrm{cm}^{-3}\right)$ in the interfacial layers of the microjets 
under such conditions (See Fig. S2, ESI $\dagger$ ). The surface density, $\left.\mathrm{S}_{\mathrm{NO}_{3}}{ }^{-}\right)$[molecules $\left.\mathrm{cm}^{-2}\right]$, of the $\mathrm{NO}_{3}{ }^{-}$produced in liquid layers of thickness $\delta$ during $\mathrm{NO}_{2}(\mathrm{~g})$ collisions on aqueous microjets, is given by the kinetic theory of gases, eqn (E1): ${ }^{59}$

$$
\mathrm{S}\left(\mathrm{NO}_{3}{ }^{-}\right)=\delta\left[\mathrm{NO}_{3}{ }^{-}\right]=(1 / 4) \gamma_{\mathrm{w}} c \tau\left[\mathrm{NO}_{2}(\mathrm{~g})\right] / 2
$$

where $\delta \sim 5 \times 10^{-8} \mathrm{~cm}$ is the average thickness of interfacial layers, $\gamma_{\mathrm{w}}$ is the uptake coefficient of $\mathrm{NO}_{2}(\mathrm{~g})$ on water, $c=3.72 \times 10^{4} \mathrm{~cm} \mathrm{~s}^{-1}$ is the mean speed of $\mathrm{NO}_{2}$ molecules at $300 \mathrm{~K}$, and $\tau>10 \mu \mathrm{s}$ is a lower bound to $\mathrm{NO}_{2}(\mathrm{~g}) /$ microjets contact time. ${ }^{52}$ Thus, we estimate that $\gamma_{\mathrm{w}}<2 \times 10^{-7}$, in accordance with previous results on the negligible uptake of $\mathrm{NO}_{2}(\mathrm{~g})$ on pure water obtained by independent techniques. ${ }^{57,58}$ The exceedingly low probability of $\mathrm{R} 1$ on pure water is supported by $\mathrm{MD}$ calculations showing that the hydrophobic free radical $\mathrm{NO}_{2}$ has strong propensity for the surface of neutral clusters $\mathrm{NO}_{2}\left(\mathrm{H}_{2} \mathrm{O}\right)_{n} \cdot{ }^{60}$

In striking contrast (but in accordance with the cloud-chamber Berkeley experiments on $\mathrm{NaCl}$-seeded droplets $)^{61}$ we found that the uptake of $\mathrm{NO}_{2}(\mathrm{~g})$ increases dramatically in the presence of anions in the sub-millimolar range. Anions are known to be selectively enriched at the air-water interface according to their size. ${ }^{54,62,63}$ Under present conditions, dicarboxylic acids ( $K_{1}=2.8$ (MA), 4.3 (GTR), 2.1 (GTM)) are largely present as monoanions. The curves in Fig. 1 correspond to Langmuir adsorption functionals: $I_{62}=I_{62, \mathrm{MAX}} \times\left[\right.$ acid] $/\left(K_{1 / 2}+\right.$ [acid]), with $K_{1 / 2} \sim(20 \pm 5) \mu \mathrm{M}$ in all cases. The curves in Fig. 2 correspond to a $I_{62}$ $\propto\left[\mathrm{NO}_{2}\right]^{\alpha}$ functional with $\alpha \sim 0.5$ in all cases. An apparent kinetic order of $\alpha \sim 0.5$ is consistent with a bimolecular reaction R1 proceeding via a multistep mechanism whose rate determining step involves one $\mathrm{NO}_{2}$ molecule (see below). Since at $\left[\mathrm{NO}_{2}(\mathrm{~g})\right]=1 \mathrm{ppmv},\left[\mathrm{N}_{2} \mathrm{O}_{4}\right] /\left[\mathrm{NO}_{2}\right]=K_{\text {Dimerization }}\left[\mathrm{NO}_{2}\right]=2.5 \times 10^{-19} \mathrm{~cm}^{3}$ molecule ${ }^{-1}\left[\mathrm{NO}_{2}\right]<1 \times 10^{-5}$, the participation of $\mathrm{N}_{2} \mathrm{O}_{4}$ in these events is

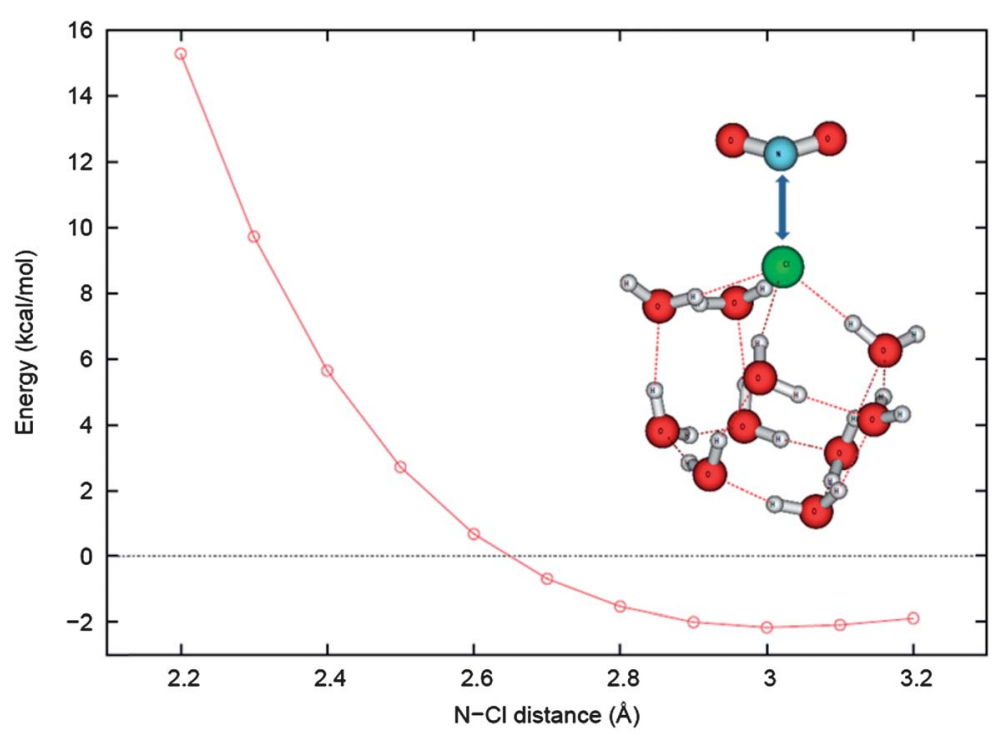

Fig. 3 Potential energy diagram for the interaction between $\mathrm{NO}_{2}$ and a $\left[\left(\mathrm{H}_{2} \mathrm{O}\right)_{10}-\mathrm{Cl}\right]^{-}$cluster. The energy between $\mathrm{NO}_{2}$ and $\left[\left(\mathrm{H}_{2} \mathrm{O}\right)_{10}-\mathrm{Cl}\right]^{-}$cluster is defined as the energy to separate $\mathrm{NO}_{2}$ from the optimized clusters to infinity without geometry relaxation. See main text for details on the calculations. 
insignificant. From the ratio of $I_{62}$ signal intensities in the presence and absence of carboxylate anions: $I_{62}$ (anions) $/ I_{62}$ (water) $\sim \gamma / \gamma_{\mathrm{w}}$, we estimate that reactive $\mathrm{NO}_{2}$ uptake coefficients increase with anion concentrations from $\gamma_{\mathrm{w}} \sim 10^{-7}$ up to $\gamma \sim$ $10^{-4}-10^{-3}$ values in the $\mu \mathrm{M}$ to $\mathrm{mM}$ range. ${ }^{46,47}$ The range of our reported $\gamma$ values is a conservative estimate based on the reproducibility of a series of experiments in which we alternated the use of water and electrolytes as liquids.

\section{Computational results}

To gain deeper molecular insights into the interactions underlying our experimental observations, we performed quantum mechanical calculations on $\mathrm{NO}_{2}-$ $\left[\left(\mathrm{H}_{2} \mathrm{O}\right)_{10}-\mathrm{Cl}\right]^{-}$and $\mathrm{NO}_{2}-\left[\left(\mathrm{H}_{2} \mathrm{O}\right)_{10}\right]$ clusters. From the rather similar effects of different anions, $\mathrm{X}^{-}$, on $\gamma$ we observed in our previous experiments, ${ }^{46,47}$ we inferred the operation of a non-specific $\mathrm{NO}_{2}-\mathrm{X}^{-}$interaction. This contention is confirmed by our calculations. The energy of the clusters was optimized at the MP2/6-31G level, and their single point energies were refined by $\operatorname{CCSD}(\mathrm{T}) / 6-31 \mathrm{G}$ augmented with d-orbitals on $\mathrm{N}$ and $\mathrm{O}$ of $\mathrm{NO}_{2}$ and $\mathrm{Cl}$. The interaction energy $E_{\text {int }}$ between $\mathrm{NO}_{2}$ and $\left[\left(\mathrm{H}_{2} \mathrm{O}\right)_{10}-\mathrm{Cl}\right]^{-}$or $\left[\left(\mathrm{H}_{2} \mathrm{O}\right)_{10}\right]$ clusters is defined as the energy to separate $\mathrm{NO}_{2}$ from the optimized clusters to infinity without geometry relaxation. MP2 and CCSD(T) calculations were carried out with GAMESS ${ }^{64}$ and NWChem, ${ }^{\mathbf{6 5}, 66}$ respectively. Ten water molecules were considered the minimum number required to solvate $\mathrm{Cl}^{-}$on the water surface. We found that $E_{\text {int }}=$ $-0.5 \mathrm{kcal} \mathrm{mol}{ }^{-1}$ for $\mathrm{NO}_{2}-\left[\left(\mathrm{H}_{2} \mathrm{O}\right)_{10}\right]$ and $E_{\text {int }}=-2.2 \mathrm{kcal} \mathrm{mol}^{-1} \mathrm{NO}_{2}-\left[\left(\mathrm{H}_{2} \mathrm{O}\right)_{10^{-}}\right.$ $\mathrm{Cl}]^{-}$. The minimum of the potential energy surface (PES) along the $\mathrm{N}-\mathrm{Cl}$ distance occurs at a $3.0 \AA$ separation (Fig. 3). The small value of $E_{\text {int }}=-2.2 \mathrm{kcal}$ $\mathrm{mol}^{-1}$ is consistent with a non-covalent interaction between $\mathrm{N}$ and $\mathrm{Cl}^{-}$. The significant difference between the gas-phase electron affinities, EA, of $\mathrm{Cl}$ (EA = $3.61 \mathrm{eV})$ and $\mathrm{NO}_{2}(\mathrm{EA}=2.27 \mathrm{eV}): \Delta \mathrm{EA}=31 \mathrm{kcal} \mathrm{mol}^{-1}$, which would be barely compensated by the creation of an incipient single $\mathrm{Cl}-\mathrm{NO}_{2}$ bond $\left(33 \mathrm{kcal} \mathrm{mol}^{-1}\right.$ in nitryl chloride), ${ }^{\mathbf{1 2}}$ prevents the development of covalent bonding via partial charge transfer from $\mathrm{Cl}^{-}$to the semi-occupied molecular orbital of $\mathrm{NO}_{2}$. We also found that in the optimized $\mathrm{NO}_{2}-\left[\left(\mathrm{H}_{2} \mathrm{O}\right)_{10}-\mathrm{Cl}\right]^{-}$cluster the negative charge largely remains localized on $\mathrm{Cl}^{-}$(the Mulliken charge of $\mathrm{Cl}^{-}$is -0.80 at the MP2 level). In fact, the electrostatic interaction between $\mathrm{Cl}^{-}$and $\mathrm{NO}_{2}$ in a point-like charge model, $E_{\mathrm{int}}=2.1 \mathrm{kcal} \mathrm{mol}^{-1}$, closely matches the magnitude of interaction energy calculated from $\operatorname{CCSD}(\mathrm{T})$. We infer that the binding between $\mathrm{NO}_{2}$ and a $\left[\left(\mathrm{H}_{2} \mathrm{O}\right)_{10}-\mathrm{Cl}\right]^{-}$cluster is fully accounted for by electrostatic, charge-dipole interactions. The fact that the interaction is purely electrostatic implies that anions in general will catalyze reaction R3, as we found experimentally. This interaction is long-ranged and prolongs the lifetime of $\mathrm{NO}_{2}$ on the surface, thereby enhancing the probability of reaction with a second $\mathrm{NO}_{2}$ molecule. A previous theoretical study ${ }^{67}$ revealed that two $\mathrm{NO}_{2}$ molecules held together by a $\mathrm{Cl}^{-}$dimerize to cis-ONONO${ }_{2}$ via a modest $1.9 \mathrm{kcal} \mathrm{mol}^{-1}$ enthalpy barrier; cis$\mathrm{ONONO}_{2}$ can then proceed to trans-ONONO${ }_{2}$ (via a $2.4 \mathrm{kcal} \mathrm{mol}^{-1}$ enthalpy barrier) or react with water to form $\mathrm{HONO}, \mathrm{H}^{+}$and $\mathrm{NO}_{3}{ }^{-}$. Njegic et al. ${ }^{68}$ found that the activation energy for cis-ONO- $\mathrm{NO}_{2}$ reacting with $\mathrm{H}_{2} \mathrm{O}$ is only $8.7 \mathrm{kcal}$ $\mathrm{mol}^{-1}$ (at the $\operatorname{CCSD}(\mathrm{T}) / \mathrm{cc}-\mathrm{pVTZ}$ level). However, Zhu et al. found the hydrolysis barrier for cis-ONO-NO $\mathrm{NO}_{2}$ is $7.1 \mathrm{kcal} \mathrm{mol}{ }^{-1}$ and for trans-ONO- $\mathrm{NO}_{2}$ is $2.3 \mathrm{kcal}$ $\mathrm{mol}^{-1}$ at the $\operatorname{CCSD}(\mathrm{T}) / 6-311++\mathrm{G}(3 \mathrm{df}, 2 \mathrm{p})$ level. ${ }^{69}$ With such low enthalpy barriers, 
the overall reaction rate is determined by the free energy barrier, i.e., by the concentration of $\mathrm{NO}_{2}$ in the gas-phase. Thus, we conclude that the interaction between $\mathrm{NO}_{2}$ and a $\left[\left(\mathrm{H}_{2} \mathrm{O}\right)_{10^{-}} \mathrm{Cl}\right]^{-}$cluster is purely electrostatic and, hence, confirm that all anions $\left(\mathrm{X}^{-}\right)$should catalyze reaction $\mathrm{R} 1$, in accord with our experimental observations. ${ }^{45-47}$ Our calculations are also consistent with recent molecular dynamics calculations. ${ }^{70}$

The preceding observations are accounted for by the following mechanism:

$$
\begin{gathered}
\mathrm{X}_{\text {interface }}^{-}+\mathrm{NO}_{2}(\mathrm{~g}) \stackrel{\text { slow }}{\longrightarrow}\left[\mathrm{X}-\mathrm{NO}_{2}{ }^{--}\right] \text {interface } \\
{\left[\mathrm{X}-\mathrm{NO}_{2}{ }^{--}\right]_{\text {interface }}+\mathrm{NO}_{2}(\mathrm{~g})+\mathrm{H}_{2} \mathrm{O} \stackrel{\text { fast }}{\longrightarrow} \mathrm{X}^{-}+\mathrm{HONO}+\mathrm{NO}_{3}{ }^{-}+\mathrm{H}^{+}}
\end{gathered}
$$

In which $\mathrm{NO}_{2}(\mathrm{~g})$ disproportionates in two steps, reactions $\mathrm{R} 7$ and R8, through the intermediacy of persistent, interfacial $\mathrm{X}-\mathrm{NO}_{2} \cdot{ }^{-}$adducts. According to this mechanism, the overall rate of $\mathrm{R} 1$ is controlled by the slow uptake of $\mathrm{NO}_{2}$ via $\mathrm{R} 7$. The probability that a second $\mathrm{NO}_{2}(\mathrm{~g})$ molecule reacts with interfacial $\mathrm{X}-\mathrm{NO}_{2}{ }^{-}$ adducts, reaction $\mathrm{R} 8$, is significantly higher than that of reaction $\mathrm{R} 7$. The catalytic role of anions in $\mathrm{R} 7$ has been clearly demonstrated in similar experiments in this setup, in which the enhanced production of $\mathrm{NO}_{3}{ }^{-}$in the presence of various $\mathrm{X}^{-}$ was not accompanied by $\mathrm{X}^{-}$losses except in the case of $\mathrm{X}^{-}=\mathrm{I}^{-}$, which was partially oxidized to $\mathrm{I}_{2}{ }^{-} \cdot{ }^{47}$ Thus, the enhancement of $\mathrm{NO}_{2}(\mathrm{~g})$ uptake by anions is simply a case of general base catalysis.

\section{Tropospheric aerosols: optical depths and anion loadings}

It is a remarkable fact that the global distribution of tropospheric aerosols, as characterized by satellite sightings, shows weak seasonal and interannual variations. ${ }^{49,50}$ For example, a $67-$ month time series of daytime column aerosol optical depths (AOD) over land: AOD $(532 \mathrm{~nm})=0.145 \pm 0.0228$ (all-sky) and $0.179 \pm$ 0.0257 (cloud-free) merely display $\sim 15 \%$ variations overall..$^{50}$ This finding is a direct indication that aerosol has multiple, uncorrelated sources, and that the photochemistry involved is complex, indeed more complex than currently envisioned. Thus, although the composition of SOA varies daily with sunlight, as expected from components of photochemical origin, ${ }^{48}$ seasonal trends tend to be rather flat (within a factor of 2) over most megacities, ${ }^{49}$ such as Los Angeles, ${ }^{71}$ Istanbul, ${ }^{72}$ Paris, ${ }^{73}$ Moscow,${ }^{74}$ Seoul, ${ }^{75}$ Beijing, Chongqing, Shanghai, Chengdu and Guangzhou, ${ }^{18,76}$ Pearl River Region (China), ${ }^{77}$ Delhi, ${ }^{78}$ and Tokyo. ${ }^{48}$ For example, the gravimetric mass concentration of ultrafine particles (i.e., the major contributors to number density and specific surface) in Los Angeles, changes from $\sim 6 \mu \mathrm{g} \mathrm{m} \mathrm{m}^{-3}$ in spring to $\sim 10 \mu \mathrm{g} \mathrm{m}^{-3}$ in fall and winter. ${ }^{71}$ The ionic mass over Istanbul steadily increased, i.e., without showing major seasonal oscillations, from $10 \mu \mathrm{g} \mathrm{m}^{-3}$ in November 07 to $20 \mu \mathrm{g} \mathrm{m}{ }^{-3}$ in June $09 .{ }^{72}$ Perhaps not unexpectedly, Moscow is less typical: atmospheric aerosol number densities show more pronounced seasonal variability, peaking in winter at values 3-4 times higher than at midsummer. ${ }^{74}$

We have shown in the laboratory that all anions, organic and inorganic, ${ }^{45-47}$ catalyze reaction R1. Organic acids are produced as ubiquitous components of 
SOA via in situ oxidation of the water-soluble compounds generated in the photo-oxidation of volatile organic compounds VOCs., ${ }^{7,72,78-80}$ Mono and dicarboxylic acids in urban atmospheres systematically increase during the morning peaking at noon, as reported by Kawamura et al., ${ }^{48}$ and are highly correlated with non-sea salt sulfate (the most abundant anion throughout) by sharing a common photochemical origin. ${ }^{79,81-83}$ Summing up, extensive groundbased and remote data show that mass concentrations and anion makeup of tropospheric aerosols display daily cycles that average out into seasonal variations within a factor of $\sim 2$.

\section{Seasonal and latitudinal variations of $J\left(\mathrm{NO}_{2}\right), J\left(\mathrm{O}^{1} \mathrm{D}\right)$ and $J(\mathrm{HONO})$ photolysis frequencies}

The frequencies at which $\mathrm{NO}_{2}, \mathrm{O}_{3}$ and HONO are photo-dissociated by sunlight via reactions R2, R4 and R6, respectively, are strong functions of zenith angle $\varphi$. Thus, $J\left(\mathrm{NO}_{2}\right)=1.7 \times 10^{-2} \mathrm{~s}^{-1}=4.5 J(\mathrm{HONO})=222 J\left(\mathrm{O}^{1} \mathrm{D}\right)$ at $\varphi=0^{\circ}$, and $J\left(\mathrm{NO}_{2}\right)=$ $5 \times 10^{-3} \mathrm{~s}^{-1}=4.7 J(\mathrm{HONO})=1280 J\left(\mathrm{O}^{1} \mathrm{D}\right)$ at $\varphi=70^{\circ}$ (Fig. $\left.\mathrm{S} 3 \dagger\right){ }^{20}$ Since $J\left(\mathrm{O}^{1} \mathrm{D}\right)$ is the lowest frequency under all conditions, it might be inferred that photostationary $\mathrm{OH}$ concentrations will be always determined by ozone photodissociation. ${ }^{11}$ The linear $[\mathrm{OH}] \propto J\left(\mathrm{O}^{1} \mathrm{D}\right)$ correlation found at a remote site over a 5-year period seems to confirm this contention, ${ }^{21}$ but it should not be expected to hold in general. ${ }^{25}$ In fact, there is overwhelming evidence that tropospheric $[\mathrm{OH}]$ is well buffered against $J\left(\mathrm{O}^{1} \mathrm{D}\right)$ variations in most locations. The failure of current tropospheric chemistry models to account for such crucial phenomenon has prompted various suggestions about alternative $\mathrm{OH}$ sources. ${ }^{39}$ The generalized perception is that such sources are linked to yet unidentified $\mathrm{NO}_{x}$ chemistry for no better reason that the same models systematically underpredict HONO field measurements.

\section{Observational constraints on the unknown HONO daytime source}

Three decades after the first spectroscopic detection of HONO in the atmosphere, ${ }^{84}$ and much work since, ${ }^{27,38,85-92}$ the mechanism of HONO daytime formation remains a puzzle. ${ }^{93}$ However, recent work has provided strong constraints on the unknown HONO daytime source and its relation to $\mathrm{NO}_{2}$ chemistry. ${ }^{26}$ Key findings were that the rates of HONO production during daytime, $R_{\mathrm{HONO}}$, at a given site (1) are an order of magnitude faster than extrapolated nighttime rates of the hydrolytic disproportionation of $\mathrm{NO}_{2}$ on wet surfaces, ${ }^{27}$ (2) systematically increase with solar flux, peaking at noon but, however, (3) can be accounted neither by the reaction of excited $\mathrm{NO}_{2}{ }^{*}$ with $\mathrm{H}_{2} \mathrm{O}(\mathrm{g}),{ }^{28}$ reaction $\mathrm{R} 9$ nor by the reduction of $\mathrm{NO}_{2}$ photosensitized by irradiated soot, $[\mathrm{C}-\mathrm{H}]_{\mathrm{red}}$, reaction $\mathrm{R} 10:^{46,94}$

$$
\begin{gathered}
\mathrm{NO}_{2} *+\mathrm{H}_{2} \mathrm{O}=\mathrm{HONO}+\mathrm{OH} \\
\mathrm{NO}_{2}+[\mathrm{C}-\mathrm{H}]_{\mathrm{red}} *=\mathrm{HONO}+[\mathrm{C}]_{\mathrm{ox}}
\end{gathered}
$$


Measured $R_{\mathrm{HONO}}$ at noon correspond to the conversion of $10 \%$ to $43 \% \mathrm{NO}_{2}$ into HONO per hour. ${ }^{26}$ Since a $50 \% \mathrm{NO}_{2} \rightarrow$ HONO conversion is the stoichiometric limit imposed by R1, the implication is that the 'unknown HONO daytime source' must also be a significant daytime sink (as $\mathrm{NO}_{3}{ }^{-}$) for $\mathrm{NO}_{2}$, and should therefore impact $\mathrm{NO}_{2}$ decay lifetimes. At present, it is not obvious how the heterogeneous 'dark' reaction R1 could be significantly enhanced by sunlight, ${ }^{26}$ or whether such enhancements are compatible with the kinetics of $\mathrm{NO}_{2}$ removal, ${ }^{95}$ which is generally deemed to occur exclusively in the gas-phase via reaction R11: ${ }^{96}$

$$
\mathrm{NO}_{2}+\mathrm{OH}+\mathrm{M}=\mathrm{HNO}_{3}+\mathrm{M}
$$

\section{Satellite data on $\mathrm{NO}_{2}$ decay lifetimes in urban plumes}

The conversion of the free radical $\mathrm{NO}_{2}$ into $\mathrm{HONO}$ in urban smog amounts to the reduction of $\mathrm{N}(\mathrm{Iv})$ into $\mathrm{N}(\mathrm{III})$ under oxidizing atmospheric conditions, an event made possible by the fact that endoergic $\mathrm{NO}_{2}$ can function both as oxidant and reductant in reaction R1. A substantial production of HONO at daytime therefore requires a heterogeneous process with R1 stoichiometry. However, the fast daytime conversion of $\mathrm{NO}_{2}$ into HONO via $\mathrm{R} 1$ is concomitant fast termination of $\mathrm{NO}_{2}$ as $\mathrm{NO}_{3}{ }^{-}$. Such outcome is at odds with the assumption that $\mathrm{NO}_{2}$ is removed exclusively by gas-phase $\mathrm{OH}$ via R11. Could such assumption be incorrect? Could the diurnal cycle of HONO production and the uniform long-term removal of $\mathrm{NO}_{2}$ be reconciled by the operation of reaction $\mathrm{R} 1$ ?

Beirle et al. recently reported $\mathrm{NO}_{2}$ decay lifetimes and emission strengths in urban plumes deduced from direct satellite observations. ${ }^{51}$ By monitoring various sites ranging from Singapore at $1.3^{\circ} \mathrm{N}$ to Moscow at $55.8^{\circ} \mathrm{N}$ to throughout the year, they derived $\mathrm{NO}_{2}$ emission strengths from direct $\mathrm{NO}_{2}$ column and lifetime measurements. Up to now, $\mathrm{NO}_{2}$ emission inventories have been based on e-fold $\mathrm{NO}_{2}$ lifetimes inferred from eqn (E2):

$$
\tau_{\mathrm{NO}_{2}+\mathrm{OH}, \text { model }}=\left(k_{\mathrm{NO}_{2}+\mathrm{OH}} \times[\mathrm{OH}]_{\text {model }}\right)^{-1}
$$

(i.e., by assuming that $\mathrm{NO}_{2}$ is removed via $\mathrm{R} 11$ ) by using $\mathrm{OH}$ concentrations estimated by atmospheric chemistry models: $[\mathrm{OH}]_{\text {model }}$. Fig. 4 shows how $\mathrm{NO}_{2}$ decay lifetimes should have increased from mid-summer to mid-winter from Singapore to Madrid if they were inversely proportional to [OH] (eqn (E1)) ${ }^{\mathbf{2 0}}$ and $[\mathrm{OH}] \propto J\left(\mathrm{O}^{1} \mathrm{D}\right)$. However, defying all expectations, seasonal averages of measured $\mathrm{NO}_{2}$ decay lifetimes, $\left\langle\tau_{\mathrm{NO}_{2}}\right.$,measured $\rangle$, were found to fall within a (4 \pm 1) $\mathrm{h}$ band over all cities below $40^{\circ} \mathrm{N}$ without significant seasonal trends. Even the outlier $\left\langle\tau_{\mathrm{NO}_{2} \text {, measured }}\right\rangle$ values over Madrid $\left(40.4^{\circ} \mathrm{N}\right)$ and Moscow $\left(55.8^{\circ} \mathrm{N}\right)$ were only a factor of 2 longer in winter than in summer. Clearly, the calculated $\tau_{\mathrm{NO}_{2}+\mathrm{OH} \text {,model }}$ increases vastly exceed the observational dispersion of $\left\langle\tau_{\mathrm{NO}_{2}}\right.$, measured $\rangle$ in all cases (Fig. 4) except, of course, over seasonless Singapore. The implications are that (i) if $\mathrm{NO}_{2}$ were to decay exclusively via R11, actual $\mathrm{OH}$ concentrations should not change appreciably with solar irradiance, at variance with expectations based on putative direct $[\mathrm{OH}] \propto J\left(\mathrm{O}^{1} \mathrm{D}\right)^{\beta}$ 


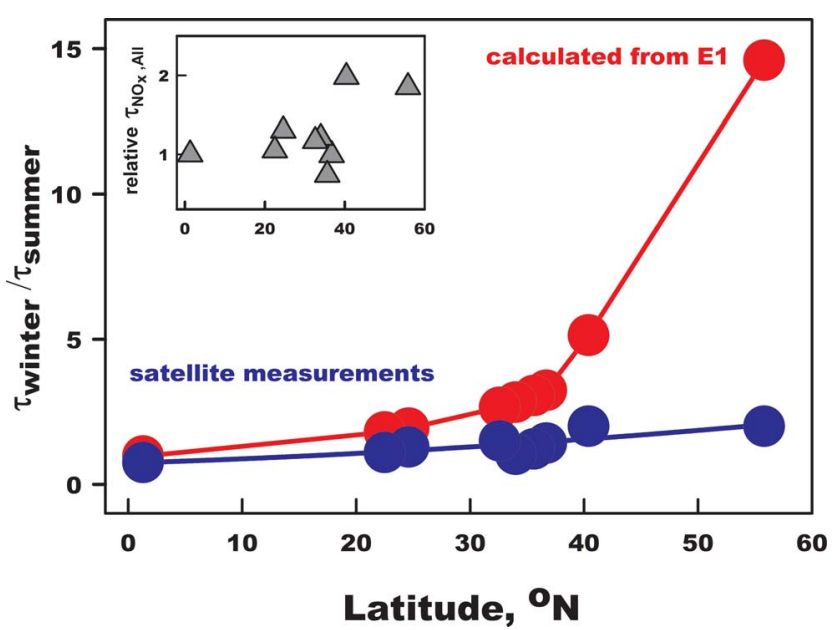

Fig. 4 Red circles and line: Ratio of e-fold $\mathrm{NO}_{2}$ decay lifetimes $\tau_{\text {winter }} / \tau_{\text {summer }}=\left\langle\tau_{\mathrm{NO}_{2}+\mathrm{OH}}\right\rangle_{\text {midwinter }} /$ $\left\langle\tau_{\mathrm{NO}_{2}+\mathrm{OH}}\right\rangle_{\text {midsummer }}$ calculated from eqn (E1) (see main text) by assuming that $\mathrm{OH}$ concentrations are proportional to $J\left(O^{1} D\right)$ (from ref. 20) the frequency of $O\left({ }^{1} D\right)$ atom production in the solar photolysis of $\mathrm{O}_{3}$, at zero elevation, surface albedo 0.4 , under an ozone column of 300 Dobson units, at noon, in midwinter and mid-summer over: (1) Singapore $1.3^{\circ} \mathrm{N}$, (2) Pearl River Delta $22.5^{\circ} \mathrm{N}$, (3) Riyadh $24.6^{\circ} \mathrm{N},(4)$

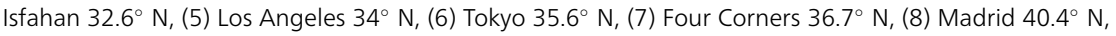
and (9) Moscow 55.8 N. Herein, mid-summer is Aug. 1st, mid-winter is Feb. 1st. Blue circles and line: Ratio of seasonal mean $\mathrm{NO}_{2}$ decay lifetimes derived from satellite sightings in plumes downwind from the same locations (ref. 51 ). Inset: $\left\langle\tau_{\mathrm{NO}_{x}, \text { All }}\right\rangle$ relative to $\left\langle\tau_{\mathrm{NO}_{x,}, \mathrm{All}}\right\rangle$ at Singapore.

correlations, ${ }^{21}$ or (ii) $\mathrm{NO}_{2}$ also decays by a competitive pathway that simultaneously buffers $\mathrm{OH}$ concentrations.

\section{How R1 buffers tropospheric OH-radicals}

Rates of the reactive dissolution of $\mathrm{NO}_{2}$ in aerosol particles wet with aqueous electrolytes can be calculated from the kinetic theory of gases as: $r(\mathrm{R} 1)=k_{\mathrm{d}}\left[\mathrm{NO}_{2}\right]$, with $k_{\mathrm{d}}=0.25 \gamma c(S / V)$, where $(S / V)$ is the combined surface of wet particles per volume of air. ${ }^{46,59}$ Typical $(S / V)$ values vary from $<2 \times 10^{-5} \mathrm{~cm}^{-1}$ in clear weather to $>5 \times 10^{-5} \mathrm{~cm}^{-1}$ during foggy events. It should be realized, however, that $(S / V)$ and total electrolyte concentrations of typical cloud and fog droplets and, hence, $\gamma$ will display wide variability over daily and weekly periods. ${ }^{97}$ Thus, by adopting a representative average value for the uptake coefficient of $\mathrm{NO}_{2}(\mathrm{~g})$ on tropospheric aerosols: $\gamma \sim 3 \times 10^{-4}$ (see above), we estimate $k_{\mathrm{d}} \sim 6 \times 10^{-5} \mathrm{~s}^{-1}$, which corresponds to $\sim 20 \% \mathrm{NO}_{2}(\mathrm{~g})$ hourly conversions in clear-day conditions, i.e., in the range of those observed in the field. ${ }^{26}$ By assuming that all HONO produced in reaction R1 is rapidly photolyzed via $\mathrm{R} 6$, the rate of $\mathrm{OH}$ production at the terminus of this route, $r_{+\mathrm{OH}}(\mathrm{R} 1)$, will therefore be given by eqn (E3):

$$
r_{+\mathrm{OH}}(\mathrm{R} 1)=r(\mathrm{R} 1)=9.3 \times 10^{3} \gamma(S / V)\left[\mathrm{NO}_{2}\right]
$$

In contrast, the production of $\mathrm{OH}$ initiated by $\mathrm{O}\left({ }^{3} \mathrm{P}\right)$ from $\mathrm{R} 2$ via $\mathrm{R} 3-\mathrm{R} 5$, $r_{+\mathrm{OH}}(\mathrm{R} 2)$, has higher losses. ${ }^{7}$ As a result, the rate of $\mathrm{OH}$ production from this pathway is significantly smaller than that of the initiation step: $r(\mathrm{R} 2)=J\left(\mathrm{NO}_{2}\right)$ 
$\left[\mathrm{NO}_{2}\right]$. By assuming the photostationary state relation: $\left[\mathrm{O}_{3}\right]=J\left(\mathrm{NO}_{2}\right)\left[\mathrm{NO}_{2}\right] /\left(k_{\mathrm{NO}+\mathrm{O} 3}\right.$ $[\mathrm{NO}])$, and taking into account that only a fraction $\theta$ of $\mathrm{O}\left({ }^{1} \mathrm{D}\right)$ from reaction $\mathrm{R} 4$ forms $\mathrm{OH}$ ( $\theta$ is an increasing function of $\mathrm{H}_{2} \mathrm{O}$ concentration), ${ }^{7}$ we obtain eqn (E4):

$$
r_{+\mathrm{OH}}(\mathrm{R} 2)=\theta J\left(\mathrm{O}^{1} \mathrm{D}\right)\left[\mathrm{O}_{3}\right] \sim \theta J\left(\mathrm{O}^{1} \mathrm{D}\right) \times J\left(\mathrm{NO}_{2}\right)\left[\mathrm{NO}_{2}\right] /\left(k_{\mathrm{NO}+\mathrm{O}}[\mathrm{NO}]\right)
$$

Since, typically, $J\left(\mathrm{NO}_{2}\right) /\left(k_{\mathrm{NO}+\mathrm{O} 3}[\mathrm{NO}]\right) \sim 1,{ }^{7}$ we get

$$
r_{+\mathrm{OH}}(\mathrm{R} 1) / r_{+\mathrm{OH}}(\mathrm{R} 2) \sim 9.3 \times 10^{3} \gamma(S / V)\left(\theta J\left(\mathrm{O}^{1} \mathrm{D}\right)\right)^{-1}
$$

For representative $\theta=0.2, J\left(\mathrm{O}^{1} \mathrm{D}\right) \sim 4 \times 10^{-5} \mathrm{~s}^{-1}$ values (Fig. S4†), the switching condition $r_{+\mathrm{OH}}(\mathrm{R} 1) / r_{+\mathrm{OH}}(\mathrm{R} 2)=1$, is reached when $\gamma(S / V) \sim 1 \times 10^{-9}$ $\mathrm{cm}^{-1}$, which should be met on realistic wet aerosols (see above). Thus, at small zenith angles (low latitudes, summertime) $\mathrm{OH}$ production is controlled by $r_{+\mathrm{OH}}(\mathrm{R} 2)$, but, when the actinic flux declines, $\mathrm{OH}$ production switches to (and never falls below) $r_{+\mathrm{OH}}(\mathrm{R} 1)$, which depends on $\langle\gamma(S / V)\rangle$ values rather than solar flux, eqn (E3) (Fig. S4†). We believe that the preceding considerations lie at the core of the mechanism by which $\mathrm{OH}$ concentrations are buffered in polluted air.

Summing up, we report laboratory results showing that carboxylate anions, such as those found in real atmospheric aerosol particles, dramatically enhance the conversion of $\mathrm{NO}_{2}(\mathrm{~g})$ to $\mathrm{HONO}(\mathrm{g})$ on the surface of water, and quantum mechanical calculations confirming that most anions will trap $\mathrm{NO}_{2}$ via electrostatics on the surface of water clusters. We also point out that recent satellite observations of $\mathrm{NO}_{2}$ evolution over several megacities exclude a dominant role for the removal of $\mathrm{NO}_{2}$ by gas-phase $\mathrm{OH}$-radicals. On this evidence, we propose that the anion-catalyzed heterogeneous disproportionation of $\mathrm{NO}_{2}\left(2 \mathrm{NO}_{2}+\mathrm{H}_{2} \mathrm{O}=\right.$ $\mathrm{H}^{+}+\mathrm{NO}_{3}{ }^{-}+\mathrm{HONO}$ ) on pervasive SOA, whose carboxylate anion content tracks photochemical activity, may both account for the time dependence of the HONO daytime source day and the dominant sink of $\mathrm{NO}_{2}$ over the course of the year. Our insights provide a causal link that bridges episodic and long-term, apparently unrelated and hitherto unexplained, observations on $\mathrm{NO}_{2} / \mathrm{HONO}$ in the lower troposphere.

\section{Acknowledgements}

SE is grateful to the Japan Science and Technology Agency (JST) PRESTO program and Steel Foundation for Environmental Protection Technology. AY is grateful to grant-in-aid from JSPS (Grant 23651014). This work was supported, in part, by NSF Grant AC1238977.

\section{References}

1 A. Sarzynski, Urban Studies, 2012, 49, 3121-3138.

2 A. M. Fiore, V. Naik, D. V. Spracklen, A. Steiner, N. Unger, et al., Chem. Soc. Rev., 2012, 41, 6663-6683.

3 M. J. Cooper, R. V. Martin, A. van Donkelaar, L. Lamsal, M. Brauer and J. R. Brook, Environ. Sci. Technol., 2012, 46, 8523-8524.

4 B. R. Gurjar, A. Jain, A. Sharma, A. Agarwal, P. Gupta, A. S. Nagpure and J. Lelieveld, Atmos. Environ., 2010, 44, 4606-4613.

5 A. J. Haagensmit, Ind. Eng. Chem., 1952, 44, 1342-1346.

6 A. J. Haagensmit, Proc. Natl. Acad. Sci. U. S. A., 1970, 67, 887-897. 
7 J. H. Seinfeld and S. N. Pandis, Atmospheric chemistry and physics: from air pollution to climate change, 2nd edn, Wiley, Hoboken, N.J., 2006.

8 T. M. Butler and M. G. Lawrence, Environ. Chem., 2009, 6, 219-225.

9 J. B. Cohen and R. G. Prinn, Atmos. Chem. Phys., 2011, 11, 7629-7656.

10 K. M. Wagstrom, S. N. Pandis, G. Yarwood, G. M. Wilson and R. E. Morris, Atmos. Environ., 2008, 42, 5650-5659.

11 D. Stone, L. K. Whalley and D. E. Heard, Chem. Soc. Rev., 2012, 41, 6348-6404.

12 NASA-JPL Chemical Kinetics and Photochemical Data for Use in Atmospheric Studies, Evaluation Number 14, 2003, http://rpw.chem.ox.ac.uk/JPL_02-25_01_intro_rev00.pdf.

13 Y. Matsumi and M. Kawasaki, Chem. Rev., 2003, 103, 4767-4781.

14 M. Kulmala, A. Asmi, H. K. Lappalainen, U. Baltensperger, J. L. Brenguier, et al., Atmos. Chem. Phys., 2011, 11, 13061-13143.

15 M. Labriet, N. Caldes and L. Izquierdo, International Journal of Global Warming, 2009, 1, 144-159.

16 C. X. Cai, C. Hogrefe, P. Katsafados, G. Kallos, M. Beauharnois, et al., Atmos. Environ., 2008, 42, 8585-8599.

17 P. Alpert, O. Shvainshtein and P. Kishcha, American Journal of Climate Change, 2012, 1, 117-131.

18 M. Lin, J. Tao, C. Y. Chan, J. J. Cao, Z. S. Zhang, L. H. Zhu and R. J. Zhang, Aerosol Air Qual Res, 2012, 12, 1049.

19 J. L. An, Y. Li, Y. Chen, J. Li, Y. Qu and Y. J. Tang, Adv. Atmos. Sci., 2013, 30, 57-66.

20 Tropospheric Ultraviolet and Visible (TUV) Radiation Model, http://cprm.acd.ucar.edu/ Models/TUV/Interactive_TUV/.

21 F. Rohrer and H. Berresheim, Nature, 2006, 442, 184-187.

22 K. D. Lu, F. Rohrer, F. Holland, H. Fuchs, B. Bohn, et al., Atmos. Chem. Phys., 2012, 12, 1541-1569.

23 S. A. Montzka, M. Krol, E. Dlugokencky, B. Hall, P. Jockel and J. Lelieveld, Science, 2011, 331, 67-69.

24 W. P. L. Carter and J. H. Seinfeld, Atmos. Environ., 2012, 50, 255-266.

25 D. E. Heard, L. J. Carpenter, D. J. Creasey, J. R. Hopkins, J. D. Lee, et al., Geophys. Res. Lett., 2004, 31, DOI: 10.1029/2004gl020544.

26 M. Sorgel, E. Regelin, H. Bozem, J. M. Diesch, F. Drewnick, et al., Atmos. Chem. Phys., 2011, 11, 10433-10447.

27 J. Kleffmann, ChemPhysChem, 2007, 8, 1137-1144.

28 S. P. Li, J. Matthews and A. Sinha, Science, 2008, 319, 1657-1660.

29 A. R. Reisinger, Atmos. Environ., 2000, 34, 3865-3874.

30 R. Zhang, G. Sarwar, J. C. H. Fung, A. K. H. Lau and Y. H. Zhang, Adv. Meteorol., 2012, DOI: $10.1155 / 2012 / 140932$.

31 Y. Sosedova, A. Rouviere, T. Bartels-Rausch and M. Ammann, Photochem. Photobiol. Sci., 2011, 10, 1680-1690.

32 M. Qin, P. H. Xie, H. Su, J. W. Gu, F. M. Peng, et al., Atmos. Environ., 2009, 43, 57315742.

33 C. George, R. S. Strekowski, J. Kleffmann, K. Stemmler and M. Ammann, Faraday Discuss., 2005, 130, 195-210.

34 C. E. Kolb, R. A. Cox, J. P. D. Abbatt, M. Ammann, E. J. Davis, et al., Atmos. Chem. Phys., 2010, 10, 10561-10605.

35 J. P. D. Abbatt, A. K. Y. Lee and J. A. Thornton, Chem. Soc. Rev., 2012, 41, 6555-6581.

36 R. Van Dingenen, J. Van Aardenne, F. Dentener, E. Marmer, E. Vignati, P. Russ, L. Szabo and F. Raes, Geochim Cosmochim Ac, 2009, 73, A1369-A1369.

37 D. J. Jacob, Atmos. Environ., 2000, 34, 2131-2159.

38 G. Lammel and J. N. Cape, Chem. Soc. Rev., 1996, 25, 361-369.

39 G. Li, W. Lei, M. Zavala, R. Volkamer, S. Dusanter, P. Stevens and L. T. Molina, Atmos. Chem. Phys., 2010, 10, 6551-6567.

40 K. Stemmler, M. Ammann, C. Donders, J. Kleffmann and C. George, Nature, 2006, 440, 195-198.

41 S. Enami, M. R. Hoffmann and A. J. Colussi, Proc. Natl. Acad. Sci. U. S. A., 2008, 105, 73657369.

42 H. Mishra, S. Enami, R. J. Nielsen, L. A. Stewart, M. R. Hoffmann, W. A. Goddard and A. J. Colussi, Proc. Natl. Acad. Sci. U. S. A., 2012, 109, 18679-18683.

43 H. Mishra, S. Enami, R. J. Nielsen, M. R. Hoffmann, W. A. Goddard and A. J. Colussi, Proc. Natl. Acad. Sci. U. S. A., 2012, 109, 10228-10232.

44 S. Enami, M. R. Hoffmann and A. J. Colussi, J. Phys. Chem. Lett., 2012, 3, 3102-3108.

45 S. Enami, M. R. Hoffmann and A. J. Colussi, J. Phys. Chem. B, 2009, 113, 7977-7981.

46 T. Kinugawa, S. Enami, A. Yabushita, M. Kawasaki, M. R. Hoffmann and A. J. Colussi, Phys. Chem. Chem. Phys., 2011, 13, 5144-5149. 
47 A. Yabushita, S. Enami, Y. Sakamoto, M. Kawasaki, M. R. Hoffmann and A. J. Colussi, J. Phys. Chem. A, 2009, 113, 4844-4848.

48 K. Kawamura and O. Yasui, Atmos. Environ., 2005, 39, 1945-1960.

49 D. M. Giles, AERONET Aerosol Optical Depth, Goddard Space Center, http:// aeronet.gsfc.nasa.gov/new_web/index.html.

50 D. M. Winker, J. L. Tackett, B. J. Getzewich, Z. Liu, M. A. Vaughan and R. R. Rogers, Atmos. Chem. Phys., 2013, 13, 3345-3361.

51 S. Beirle, K. F. Boersma, U. Platt, M. G. Lawrence and T. Wagner, Science, 2011, 333, 17371739.

52 S. Enami, M. R. Hoffmann and A. J. Colussi, J. Phys. Chem. Lett., 2010, 1, 1599-1604.

53 S. Enami, C. D. Vecitis, J. Cheng, M. R. Hoffmann and A. J. Colussi, Chem. Phys. Lett., 2008, 455, 316-320.

54 J. Cheng, C. D. Vecitis, M. R. Hoffmann and A. J. Colussi, J. Phys. Chem. B, 2006, 110, 25598-25602.

55 J. S. Jung, B. Tsatsral, Y. J. Kim and K. Kawamura, J. Geophys. Res., 2010, 115, DOI: 10.1029/2010jd014339.

56 Y. N. Lee and S. E. Schwartz, J. Geophys. Res. Atmos., 1981, 86, 1971-1983.

57 S. E. Schwartz and Y. N. Lee, Atmos. Environ., 1995, 29, 2557-2559.

58 J. Kleffmann, K. H. Becker and P. Wiesen, Atmos. Environ., 1998, 32, 2721-2729.

59 P. Davidovits, C. E. Kolb, L. R. Williams, J. T. Jayne and D. R. Worsnop, Chem. Rev., 2006, 106, 1323-1354.

60 D. S. Bezrukov and Y. V. Novakovskaya, Struct. Chem., 2004, 15, 77-81.

61 A. Bambauer, B. Brantner, M. Paige and T. Novakov, Atmos. Environ., 1994, 28, 32253232 .

62 J. Cheng, M. R. Hoffmann and A. J. Colussi, J. Phys. Chem. B, 2008, 112, 71577161.

63 J. Cheng, E. Psillakis, M. R. Hoffmann and A. J. Colussi, J. Phys. Chem. A, 2009, 113, 81528156.

64 M. W. Schmidt, K. K. Baldridge, J. A. Boatz, S. T. Elbert, M. S. Gordon, et al., J. Comput. Chem., 1993, 14, 1347-1363.

65 M. Valiev, E. J. Bylaska, N. Govind, K. Kowalski, T. P. Straatsma, et al., Comput. Phys. Commun., 2010, 181, 1477-1489.

66 S. Hirata, J. Phys. Chem. A, 2003, 107, 9887-9897.

67 W.-G. Liu and W. A. Goddard, J. Am. Chem. Soc., 2012, 134, 12970-12978.

68 B. Njegic, J. D. Raff, B. J. Finlayson-Pitts, M. S. Gordon and R. B. Gerber, J. Phys. Chem. A, 2010, 114, 4609-4618.

69 R. S. Zhu, K. Y. Lai and M. C. Lin, J. Phys. Chem. A, 2012, 116, 4466-4472.

70 G. Murdachaew, M. E. Varner, L. F. Phillips, B. J. Finlayson-Pitts and R. B. Gerber, Phys. Chem. Chem. Phys., 2013, 15, 204-212.

71 N. Daher, S. Hasheminassab, M. M. Shafter, J. J. Schauer and C. Sioutas, Environm. Sci. Processes Impacts, 2013, 15, 283-295.

72 C. Theodosi, U. Im, A. Bougiatioti, P. Zarmpas, O. Yenigun and N. Mihalopoulos, Sci. Total Environ., 2010, 408, 2482-2491.

73 M. Bressi, J. Sciare, V. Ghersi, N. Bonnaire, J. B. Nicolas, et al., Atmos Chem Phys, 2013, 13, 29391-29442.

74 N. O. Plaude, E. A. Stulov, I. P. Parshutkina, E. V. Sosnikova, N. A. Monakhova and V. V. Yakhno, Russ. Meteorol. Hydrol., 2012, 37, 21-27.

75 W. Kim, H. Lee, J. Kim, U. Jeong and J. Kweon, Atmos. Environ., 2012, 56, 101-108.

76 T. G. Theofanous, V. V. Mitkin, C. L. Ng, C. H. Chang, X. Deng and S. Sushchikh, Phys. Fluids, 2012, 24, 022104.

77 K. F. Ho, S. S. H. Ho, S. C. Lee, K. Kawamura, S. C. Zou, J. J. Cao and H. M. Xu, Atmos. Chem. Phys., 2011, 11, 2197-2208.

78 L. Zhang, D. J. Jacob, E. M. Knipping, N. Kumar, J. W. Munger, C. C. Carouge, A. van Donkelaar, Y. X. Wang and D. Chen, Atmos. Chem. Phys., 2012, 12, 4539-4554.

79 J. Z. Yu, X. F. Huang, J. H. Xu and M. Hu, Environ. Sci. Technol., 2005, 39, 128-133.

80 N. Takegawa, T. Miyakawa, Y. Kondo, J. L. Jimenez, Q. Zhang, D. R. Worsnop and M. Fukuda, J. Geophys. Res., 2006, 111, D11206.

81 S. Myriokefalitakis, K. Tsigaridis, N. Mihalopoulos, J. Sciare, A. Nenes, K. Kawamura, A. Segers and M. Kanakidou, Atmos. Chem. Phys., 2011, 11, 5761-5782.

82 Y. Kanaya, R. Q. Cao, H. Akimoto, M. Fukuda, Y. Komazaki, et al., J. Geophys. Res., 2008, 112, DOI: 10.1029/2007JD008671.

83 Y. Kanaya, M. Fukuda, H. Akimoto, N. Takegawa, Y. Komazaki, Y. Yokouchi, M. Koike and Y. Kondo, J. Geophys. Res., 2008, 113, DOI: 10.1029/2007JD008670.

84 D. Perner and U. Platt, Geophys. Res. Lett., 1979, 6, 917-920.

85 B. Aumont, F. Chervier and S. Laval, Atmos. Environ., 2003, 37, 487-498. 
86 J. Stutz, B. Alicke, R. Ackermann, A. Geyer, S. H. Wang, A. B. White, E. J. Williams, C. W. Spicer and J. D. Fast, J. Geophys. Res., 2004, 109, DOI: 10.1029/2003JD004135.

87 R. M. Harrison and G. M. Collins, J. Atmos. Chem., 1998, 30, 397-406.

88 Y. Yu, B. Galle, A. Panday, E. Hodson, R. Prinn and S. Wang, Atmos. Chem. Phys., 2009, 9, 6401-6415.

89 K. Acker, D. Beysens and D. Moller, Atmos. Res., 2008, 87, 200-212.

90 J. Notholt, J. Hjorth and F. Raes, Atmos. Environ., 1992, 26A, 211-217.

91 X. Li, T. Brauers, R. Haseler, B. Bohn, H. Fuchs, et al., Atmos. Chem. Phys., 2012, 12, 14971513.

92 P. Wojtal, J. D. Halla and R. McLaren, Atmos. Chem. Phys., 2011, 11, 3243-3261.

93 B. J. Finlayson-Pitts, Phys. Chem. Chem. Phys., 2009, 11, 7760-7779.

94 M. E. Monge, B. D'Anna, L. Mazri, A. Giroir-Fendler, M. Ammann, D. J. Donaldson and C. George, Proc. Natl. Acad. Sci. U. S. A., 2010, 107, 6605-6609.

95 B. J. Finlayson-Pitts, L. M. Wingen, A. L. Sumner, D. Syomin and K. A. Ramazan, Phys. Chem. Chem. Phys., 2003, 5, 223-242.

96 B. J. Finlayson-Pitts and J. N. Pitts, Chemistry of the upper and lower atmosphere, Academic Press, San Diego, CA, 2000.

97 A. Marinoni, P. Laj, K. Sellegri and G. Mailhot, Atmos. Chem. Phys., 2004, 4, 715-728. 